ARTICLE

\title{
Azadinium (Amphidomataceae, Dinophyceae) in the Southwest Atlantic: In situ and satellite observations
}

\author{
Azadinium (Amphidomataceae, Dinophyceae) en el Atlántico Sudoccidental: \\ Observaciones in situ y satelitales
}

\section{Rut Akselman ${ }^{1}$, Rubén M. Negri ${ }^{1}$ and Ezequiel Cozzolino ${ }^{1}$}

\begin{abstract}
${ }^{1}$ Instituto Nacional de Investigación y Desarrollo Pesquero, INIDEP, V. Ocampo 1, Escollera Norte, B7602HSA-Mar del Plata, Argentina.rutaks@inidep.edu.ar

Resumen.- Los azaspirácidos (AZAs) son toxinas identificadas en invertebrados marinos y tienen amplia distribución geográfica, no reportadas aún en Argentina ni Uruguay. Aunque el primer agente causal identificado es el dinoflagelado fotosintético Azadinium spinosum, diversos estudios indican que otras especies sintetizan asimismo AZAs. Recientemente se ha detectado la presencia de A. cf. spinosum en el Atlántico Sudoccidental y la generación de dos extensas floraciones como nuevos eventos a escala global. En este estudio se analiza la distribución geográfica regional y desarrollo temporal de Azadinium así como las condiciones ecológicas de una tercera floración de A. cf. spinosum y su registro satelital. Azadinium presentó una amplia distribución que abarcó el norte de la plataforma de Argentina y sur de Uruguay, incluyendo la desembocadura del Río de la Plata, con abundancias generalmente bajas $\left(<1 \times 10^{3}\right.$ células $\left.L^{-1}\right)$; un estudio en una estación de serie de tiempo mostró una marcada estacionalidad con mayores abundancias en primavera y otoño. La tercera floración $\left(>10^{6}\right.$ células $\left.L^{-1}\right)$ de $A$. cf. spinosum ocurrió en agosto-septiembre 1998 en un área coincidente con las previas, en condiciones hidrográficas propicias para su crecimiento poblacional. Esta floración comprobada in situ tuvo registros satelitales del sensor SeaWiFS que indicaron altas concentraciones de clorofila-a (máximo: $11,76 \mathrm{mg} \mathrm{Clo-a} \mathrm{m}^{-3}$ ) dentro de una ancha y larga banda (al menos 2,5 de latitud) adyacente al talud continental y la Corriente de Malvinas. Aún desconocemos si las especies de Azadinium presentes en el Atlántico Sudoccidental son capaces de sintetizar AZAs, tema de interés debido a la explotación de bivalvos en bancos de profundidad.
\end{abstract}

Palabras clave: Azadinium, floraciones de dinoflagelados, Atlántico Sudoccidental, SeaWiFS

\begin{abstract}
Azaspiracid toxins (AZAs) have been identified in marine invertebrates and are of wide geographical distribution, but have not been reported in Argentina or Uruguay. The first identified causal agent is the photosynthetic dinoflagellate Azadinium spinosum, but new studies indicate that other species also synthesize AZAs. We have recently reported the presence of A. cf. spinosum in the Southwest Atlantic and the generation of two extended blooms as new global events. Here we analyze the ecological conditions of a third bloom of A. cf. spinosum and its satellite record, and report the regional distribution and temporal development of the genus Azadinium. Azadinium had a wide spatial distribution encompassing northern Argentine and southern Uruguayan shelves, including the mouth of the Río de la Plata. Abundance was generally low $\left(<1 \times 10^{3}\right.$ cells $\left.\mathrm{L}^{-1}\right)$, and analysis conducted at a time series station showed a marked seasonality in spring and autumn. A. cf. spinosum caused a third bloom and discolorations $\left(>10^{6}\right.$ cells $\left.\mathrm{L}^{-1}\right)$ in August-September 1998 in the northern shelf of Argentina in an area that spatially coincided with the previous episodes, with hydrographic conditions propitious for its population growth. This bloom analyzed in situ, had satellite records from the SeaWiFS sensor which indicated high concentrations of chlorophyll-a (maximum

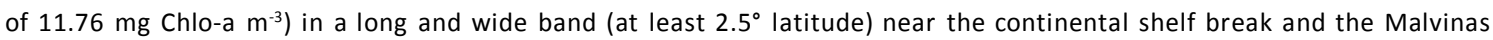
Current. It is still unknown if species of Azadinium are capable of synthesizing AZAs, a topic of interest in this region due to commercial bivalve exploitation.
\end{abstract}

Key words: Azadinium, dinoflagellate blooms, sW Atlantic, SeaWiFS

\section{INTRODUCTION}

Azadinium is a dinoflagellate genus capable of synthesizing a lipophilic group of azaspiracid phycotoxins (AZAs), whose knowledge has had a rapid advance in recent years with the description of new species, all photosynthetic and of marine planktonic habitat. On the basis of morphological analysis, molecular sequencing of ribosomal RNA and structural characterization of AZAs, it forms together with Amphidoma languida a new monophyletic clade within the subclass Peridiniphycidae to which it has been proposed as a family rank, Amphidomataceae (Tillmann et al. 2012b). Nine species of Azadinium have been described until today: 
A. spinosum Tillmann et Elbrächter, the type species (Tillmann et al. 2009), A. obesum Tillmann et Elbrächter (Tillmann et al. 2010), A. poporum Tillmann et Elbrächter (Tillmann et al. 2011), A. polongum Tillmann (Tillmann et al. 2012a), A. dexteroporum Percopo et Zingone (Percopo et al. 2013), A. dalianense Luo Z., Gu H. et Tillmann U. (Luo et al. 2013), A. trinitatum Tillmann et Nézan, A. cuneatum Tillmann et Nézan and A. concinnum Tillmann et Nézan (Tillmann et al. 2014). Recently, 2 morphotypes that had been assigned to Amphidoma caudata and to species of Oxytoxum were analyzed and transferred to Azadinium with rank of varieties: A. caudatum (Halldal) Nézan et Chomérat var. caudatum and $A$. caudatum var. margalefii (Rampi) Nézan et Chomérat (Nézan et al. 2012). Two other taxa, A. cf. poporum (Potvin et al. 2012) and A. cf. spinosum (Akselman \& Negri 2012), have been tentatively ascribed to their respective species. However, a new comparative study has assimilated the first one to A. poporum (Gu et al. 2013), while A. cf. spinosum still remains under study.

Azadinium possibly has a large geographic distribution (see Tillmann et al. 2012a, Percopo et al. 2013, Tillmann et al. 2014). A. spinosum, A. obesum, A. polongum and $A$. poporum were described after cultures of isolated cells sampled in various sites of the North Sea, while A. dexteroporum was described from the Italian coast of the Tyrrhenian Sea, A. dalianense from the Yellow Sea, China, and the recently known A. trinitatum, A. cuneatum and $A$. concinnum were isolated from sub-Arctic areas between Greenland and Iceland. A. caudatum was studied in samples from Scotland and Atlantic and Mediterranean coastal areas of France. It also occurs in other localities of the Atlantic, North Sea and Mediterranean Sea (Nézan et al. 2012). Our knowledge on the distribution of some of these species is increasing, with a taxon attributed to A. spinosum in the Mexican Pacific (Hernández-Becerril et al. 2012) and A. poporum in China and Korea (Potvin et al. 2012, Gu et al. 2013). Although recently published, the presence and bloom occurrence of $A$. cf. spinosum have been known for the Southwest Atlantic (SWA) in northern Argentina for more than two decades (Akselman \& Negri 2012).

After the first case of human poisoning by shellfish consumption (McMahon \& Silke 1996) in 1995, and characterization of the first azaspiracid AZA-1 (Satake et al. 1998), more than 30 structural variants were described.
Most of these are bivalve metabolites derived from ingested microalgae, the primary producers of toxins (Rehmann et al. 2008). Although AZAs were initially identified only in A. spinosum (Krock et al. 2009, Tillmann et al. 2009), there is an increasing evidence of a diversity of compounds from this group of toxins produced not only by some species of Azadinium (Tillmann et al. 2012a, Percopo et al. 2013) but also by Amphidoma (Krock et al. 2012). These AZAs are gradually characterized and may vary between strains of the same species as is the case of A. poporum isolates from Europe, Korea and China (Krock et al. 2012, Gu et al. 2013).

Numerous studies conducted in vivo and with in vitro cultured cell lines indicate that AZAs could produce various toxicological effects (e.g., Ito et al. 2002, Colman et al. 2005, Twiner et al. 2005, 2008, 2012; see review in Furey et al. 2010). It has also been suggested that chronic exposure to AZAs could increase a risk of tumor development due to interaction with other lipophilic toxins (Furey et al. 2010).

Azaspiracid toxins have been recorded in many regions and seem to have worldwide distribution (e.g., James et al. 2002, Magdalena et al. 2003, Twiner et al. 2008, Furey et al. 2010, Twiner et al. 2012), being known from areas in which the causal organisms have not yet been registered, as is the case of Brazil in the SWA (Schramm et al. $2010^{1}$, Odebrecht 2010). This feature is possibly due to the small size of these species, generally members of the nanoplanktonic fraction (the smallest $A$. dexteroporum: length $8.5 \mu \mathrm{m}$ ). The opposite has happened in Argentina: we have recorded the presence of $A$. cf. spinosum for over two decades (Akselman \& Negri 2012), but whether it can synthesize toxins is still unknown. This is an important regional issue due to commercial fisheries of benthic bivalve resources focused mainly on scallops (Zygochlamys patagonica King et Broderip) and mussels (Mytilus edulis Linnaeus) (Lasta et al. 1998, Ciocco et al. 2006).

Ecological conditions of growth and development of species of Azadinium at sea are little known, since the numerous studies carried on this genus have been focused principally on taxonomy, genetics and toxicology, and were done using cultures. The two major blooms of $A$. cf. spinosum in 1990 and 1991 at the SWA, which caused discolorations and high cellular abundance $\left(>10^{6}\right.$ cells $\left.\mathrm{L}^{-1}\right)$,

${ }^{1}$ Schramm MA, TP Alves, M Honorato \& LAO Proença. 2010. Primeira detecção de ficotoxinas lipofílicas em mexilhões da Armação do Itapocorói em Santa Catarina através de LC-MS/MS. 2010. In: XIII Congresso Brasileiro de Ficologia, 2010, Paraty - RJ. Resumos. p. 381 
allowed us to postulate that this dinoflagellate is a successful competitor of chained Thalassiosira species typical of the spring bloom in this region. Its development seems to be related to the annual period of temperate water regimes where turbulence begins to decay but when nutrients are still available (Margalef 1978, Akselman \& Negri 2012). In this work we extend the study of Azadinium analyzing its regional geographic distribution and temporal development, as well as a description of a third bloom of $A$. cf. spinosum and its satellite record, all of these associated to environmental conditions.

\section{MATERIALS AND METHODS}

Three type of samplings were performed. First, a cruise in the RV/E.L. Holmberg (INIDEP, EH-10/93, 34³3'S-38³0'S, 50-250 m isobaths, September 14-30, 1993) where hydrographic data as well as surface water samples for quantitative analysis of phytoplankton were obtained in order to record spatial distribution and abundance of Azadinium and ecological conditions of its development in southern Uruguayan and northern Argentinian shelves (Figs. 1 and 2). Second, observations on surface discolorations were recorded during two dates, August 28 and September 5 1998, on a cruise aboard the RV/Cap. Cánepa (INIDEP, CC-11/98) in the northern Argentine shelf. Surface water samples were collected in situ on both dates and fixed with Lugol for quantitative analysis of phytoplankton. There were also complementary hydrographic data from another cruise (EH-08/98, August 10-30, 1998) conducted during the same period, which allowed a better characterization of the area of the bloom. Third, seasonal development and interannual variability of Azadinium were analyzed in water samples obtained during 56 cruises conducted at the time-series station Estación Permanente de Estudios Ambientales 'EPEA' located 12 nautical miles from the coast ( $38^{\circ} 28^{\prime} \mathrm{S}-57^{\circ} 41^{\prime} \mathrm{W}, 48 \mathrm{~m}$ depth), from May 1994 to November 2000 (Fig. 1, Table 1). During this period, there was approximately the same number of cruises to the EPEA station in spring (September, October, November -SON-, $\mathrm{n}=16$ ), summer (December, January, February -DJF-, n= 13), autumn (March, April, May MAM-, $n=15$ ), and winter (June, July, August -JJA-, n= 12). Temperature and salinity profiles were determined in the EPEA station with a Seabird CTD Model 1901; corrections for these data were made in the Laboratory of Physical Oceanography and were provided by the Regional Oceanographic Data Base (BaRDO, INIDEP). Quantitative analyses of phytoplankton were carried out on water samples collected using a bucket for surface samples and Niskin bottles for selected depths, from

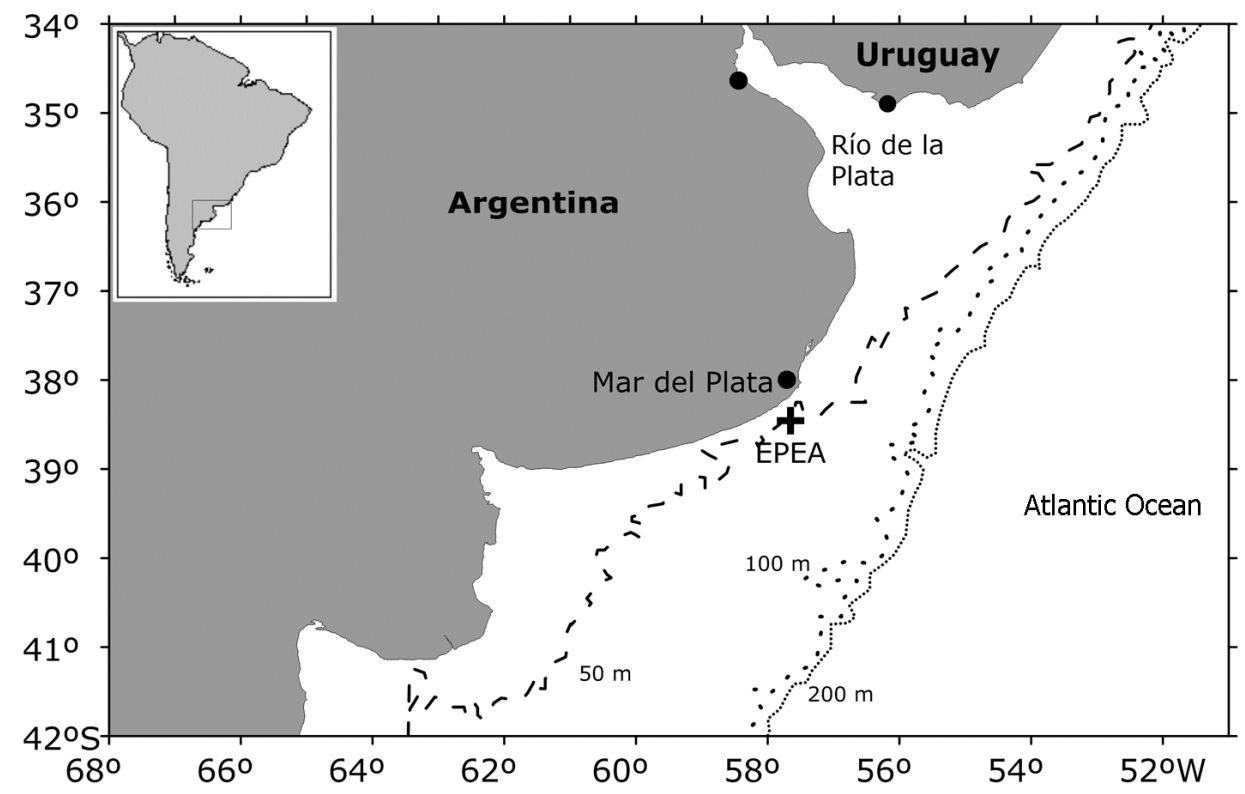

Figure 1. Study area and location of the EPEA permanent station for environmental studies / Área de estudio y localización de la Estación Permanente de Estudios Ambientales-EPEA 
Table 1. Dates of cruises made to the time-series station EPEA. Codes correspond to the INIDEP research vessels 'Capitán Cánepa' (CC), 'E.L. Holmberg' (EH) and 'Cap. Oca Balda' (OB). 'I', 'Il' in EH-06/95: first and second parts of this cruise / Fechas de campañas efectuadas a la estación de serie-de-tiempo EPEA. Los códigos corresponden a los buques de investigación pesquera del INIDEP 'Capitán Cánepa' (CC), 'E.L. Holmberg' (EH) y 'Cap. Oca Balda' (OB); 'I', 'II' en EH-06/95: primera y segunda etapa de la campaña

\begin{tabular}{llllllll}
\hline Cruise code & Year & Day & Month & Cruise code & Year & Day & Month \\
\hline EH-03/94 & 1994 & 06 & May & CC-09/96 & 1996 & 17 & December \\
EH-04/94 & 1994 & 22 & May & OB-03/97 & 1997 & 01 & February \\
EH-06/94 & 1994 & 12 & June & EH-02/97 & 1997 & 08 & April \\
EH-08/94 & 1994 & 27 & July & OB-05/97 & 1997 & 30 & April \\
EH-09/94 & 1994 & 11 & August & EH-06/97 & 1997 & 31 & May \\
OB-06/94 & 1994 & 29 & August & EH-08/97 & 1997 & 17 & June \\
OB-07/94 & 1994 & 05 & September & CC-09/97 & 1997 & 12 & September \\
OB-08/94 & 1994 & 18 & October & CC-11/97 & 1997 & 31 & October \\
EH-13/94 & 1994 & 13 & November & CC-13/97 & 1997 & 13 & November \\
OB-09/94 & 1994 & 25 & November & CC-02/98 & 1998 & 17 & February \\
EH-15/94 & 1994 & 02 & December & CC-04/98 & 1998 & 18 & March \\
OB-11/94 & 1994 & 20 & December & CC-06/98 & 1998 & 22 & April \\
EH-01/95 & 1995 & 31 & January & CC-07/98 & 1998 & 20 & May \\
EH-03/95 & 1995 & 06 & February & CC-09/98 & 1998 & 05 & August \\
EH-03/95 & 1995 & 28 & February & CC-12/98 & 1998 & 11 & September \\
OB-04/95 & 1995 & 27 & March & CC-15/98 & 1998 & 03 & November \\
OB-05/95 & 1995 & 15 & April & CC-19/98 & 1998 & 17 & December \\
OB-06/95 & 1995 & 27 & April & CC-04/99 & 1999 & 26 & February \\
EH-05/95 & 1995 & 23 & July & CC-06/99 & 1999 & 31 & May \\
OB-08/95 & 1995 & 31 & July & CC-10/99 & 1999 & 11 & August \\
EH-06/95 & 1995 & 25 & August & CC-09/00 & 2000 & 29 & March \\
EH-06/95-I & 1995 & 16 & September & CC-13/00 & 2000 & 10 & May \\
EH-06/95-II & 1995 & 28 & September & CC-15/00 & 2000 & 24 & May \\
OB-11/95 & 1995 & 21 & October & CC-17/00 & 2000 & 07 & June \\
EH-09/95 & 1995 & 13 & December & CC-19/00 & 2000 & 14 & July \\
EH-01/96 & 1996 & 05 & January & CC-29/00 & 2000 & 18 & October \\
EH-15/96 & 1996 & 20 & November & CC-32/00 & 2000 & 03 & November \\
EH-16/96 & 1996 & 04 & December & CC-34/00 & 2000 & 17 & November \\
\hline
\end{tabular}

surface, 10, 20, 30 and $45 \mathrm{~m}$ or at 100, 50, 25, 10 and $1 \%$ of light penetration depth and fixed with Lugol's solution. Light penetration and natural fluorescence profiles were obtained by a PUV-500/510B (Biospherical Instruments Inc.) underwater radiometer. Identification and quantification of cells from microplankton (20-200 $\mu \mathrm{m})$ and nanoplankton size fractions $(10-20 \mu \mathrm{m})$ were made with an Olympus IX70 inverted microscope using the Utermöhl's method (Hasle 1978). Water samples that were collected in the spring of 1993, at the area of the $A$. cf. spinosum bloom and in cruises conducted to the EPEA station were analyzed at a 400x magnification during quantification. For scanning electron microscopy, cells of water samples collected at the area of the bloom were transferred from Lugol to a formaline-acetic acid-ethanol solution and further processed according to Postek et al. (1980). Information on author names of algal species was used according to Guiry \& Guiry (2014). Satellite data from the SeaWiFS (Sea-viewing Wide Field-of-view Sensor $)^{2}$ were analyzed. The chlorophyll concentration values obtained correspond to the NASA OCv4 algorithm (O'Reilly et al. 1998, 2000). L2 GAC (Global Area Coverage) daily data with a spatial resolution of about 1 km were downloaded for the period 08/25/1998-09/07/1998. Average images for the periods 08/25/1998-08/26/1998 and 08/29/1998-09/07/1998 were developed using L3 SMI

${ }^{2}<$ http://oceancolor.gsfc.nasa.gov/> 
images (Standard Mapped Image) with a spatial resolution of $\sim 9 \mathrm{~km}$. Records of wind speed and direction obtained every $6 \mathrm{~h}$ at the vertices of the square $37-40^{\circ} \mathrm{S}$ and 57.5$55^{\circ} \mathrm{W}$ were downloaded from the website of the Earth System Research Laboratory (NCEP Reanalysis data, NOAA/OAR/ESRL PSD, Boulder, Colorado, USA) ${ }^{3}$, and analyzed for the period 08/20/1998-09/10/1998.

\section{Results}

To perform this work numerous field samples covering a wide spatio-temporal scale were used. As detailed in the paragraph of material and methods, the quantitative study of these samples was done with optical microscopy. Considering the small size of cells of Azadinium it could not be done a detailed observation of morphological characteristics related to species identification, reason why they were considered at the rank of genus, as Azadinium. However, the high cell abundance in samples from areas of surface discolorations in 1998, have allowed a detailed analysis of thecal plate configuration at higher magnification using scanning electron microscopy. In this case, the causal organism was identified as that described by Akselman \& Negri (2012) as A. cf. spinosum.

\section{GeOgRAPHIC DisTRIBUTION}

\section{SPRING 1993}

At the beginning of the spring 1993, cells of Azadinium were recorded within a wide latitudinal area of $\sim 2.5$ degrees

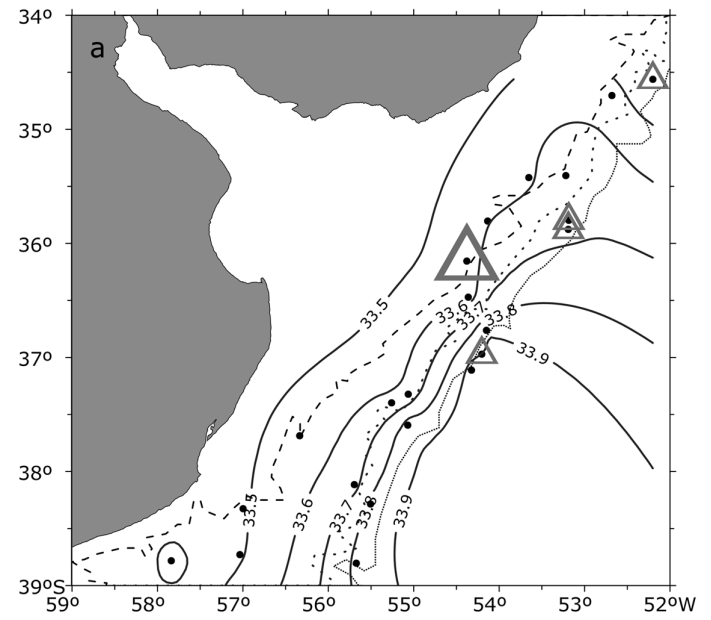

comprising shelf waters of northern Argentina and southern Uruguay between 50 and $250 \mathrm{~m}$ isopleths (Fig. 2). Azadinium was present in the marine area off the mouth of the Río de la Plata (47 $\mathrm{m}$ depth), in middle shelf waters (108-135 m depth) and in the vicinity of the shelf-break (maximum depth $245 \mathrm{~m}$ ) with abundances at the surface ranging between $0.04 \times 10^{3}$ and $35 \times 10^{3}$ cells $\mathrm{L}^{-1}$. The highest concentration was recorded off the mouth of the river in one station, while abundance was low (less than $1 \times 10^{3}$ cells $\mathrm{L}^{-1}$ ) in the remaining stations (Fig. 2).

Spatial analysis of phytoplankton composition and abundance in samples from this cruise allowed to distinguish the presence of three communities: 1- A bloom of Phaeocystis cf. pouchetii at the mouth of the Río de la Plata, 2- A community dominated by a chain-forming Thalassiosira species (maximum, $1.58 \times 10^{6}$ cells $\mathrm{L}^{-1}$ ), followed in abundance by Chaetoceros spp., Pseudonitzschia spp. and Thalassionema nitzschioides (Grunow) Mereschkowsky, on the Argentine shelf towards the South of the study area, and 3- A community with predominance of a single-cell species of Thalassiosira (maximum, $84.8 \times 10^{4}$ cells $\mathrm{L}^{-1}$ ) at the North of the mouth of the Río de la Plata and in the Uruguayan shelf. Azadinium was present in low concentrations as a member of each of these three communities, and notably, its maximum abundance occurred off the mouth of the Río de la Plata. This was a sector of high diversity at which the three phytoplankton communities converged, and in which Phaeocystis and Thalassiosira also attained their maximum abundances.

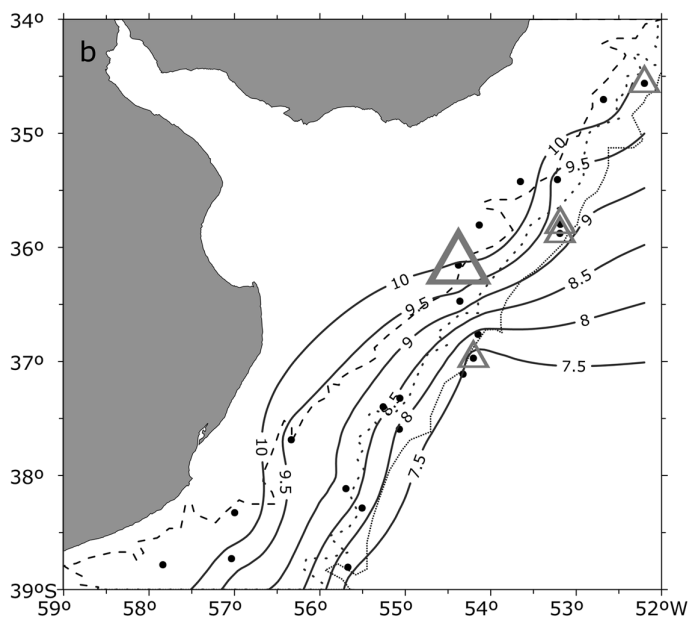

Figure 2. Presence of Azadinium (triangles) and distribution of salinity (a) and temperature in ${ }^{\circ} \mathrm{C}$ (b) in the surface area covered by the EH-10/93 cruise (September 1993; dots: location of stations, absence of Azadinium). Small triangles: < $10^{3}$ cells $\mathrm{L}^{-1}$; large triangle: $35^{3} \mathrm{C}^{3}$ cells $\mathrm{L}^{-1} /$ Presencia de Azadinium (triángulos) y distribución de salinidad (a) y temperatura en ${ }^{\circ} \mathrm{C}$ (b) de superficie en el área cubierta por la campaña EH-10/93 (septiembre 1993; puntos: localización de estaciones, ausencia de Azadinium). Triángulos pequeños: $<10^{3}$ células $\mathrm{L}^{-1}$; triángulo grande: $3510^{3}$ células $\mathrm{L}^{-1}$

${ }^{3}<$ http://www.esrl.noaa.gov/psd/> 


\section{The 1998 A. CF. SPINOSUM BLOOM}

During a cruise carried out in late winter/early spring of 1998 in the northern Argentine shelf, areas of water discolorations were seen offshore $(\sim 190 \mathrm{~km})$ in the region adjacent to the shelf break at depths near the $200 \mathrm{~m}$ isobath. Surface discolorations, reported as dark brown, were observed on August 28 during a first part of the cruise in position $38^{\circ} 50^{\prime} \mathrm{S}-55^{\circ} 35^{\prime} \mathrm{W}$, and September 5 during a second part in position $39^{\circ} 30^{\prime} \mathrm{S}-56^{\circ} 00^{\prime} \mathrm{W}$ (Fig. 3). Microscopic analysis of samples obtained in both areas pointed out that Azadinium cf. spinosum was the causal species of this bloom. Concentration of $A$. cf. spinosum in all samples was higher than $1 \times 10^{6}$ cells $\mathrm{L}^{-1}$, with a maximum value of $4.7 \times 10^{6}$ cells $\mathrm{L}^{-1}$ and percentages $>95 \%$ of the total number of cells in the size fractions of nano $(10-20 \mu \mathrm{m})$ and microplankton $(20-200 \mu \mathrm{m})$. Other species of this community were the photosynthetic dinoflagellates Scrippsiella trochoidea (Stein) Balech ex Loeblich, Gonyaulax spinifera (Claparède et Lachmann) Diesing, Gonyaulax turbynei Murray et Whitting, Prorocentrum cf. balticum and Gymnodinium sp., the heterotrophic Oxytoxum sp., an athecate dinoflagellate and an unidentified nanoplanktonic euglenophyte, all of them at low concentrations not exceeding $1 \times 10^{3}$ cells $\mathrm{L}^{-1}$, except for $S$. trochoidea $\left(2 \times 10^{5}\right.$ cells $\left.\mathrm{L}^{-1}\right)$. The athecate dinoflagellate was a non photosynthetic species, of which some specimens showed recently ingested $A$. cf. spinosum cells. The distance between the positions of the discolorations registered in the two parts of the cruise spanned a length of $\sim 40^{\prime}$ in latitude and $25^{\prime}$ in longitude, evidencing that the area occupied by the bloom of $A$. cf. spinosum was extense. Moreover, the period between the two observations was nine days, so that this bloom lasted a relatively long period of time.

The 1998 bloom of $A$. cf. spinosum was also detected by color satellite images obtained during the period when water samples were collected in situ at the two parts of the cruise (Fig. 4). Satellite data of surface chlorophyll-a concentration (Chlo-a) obtained by SeaWiFS daily images, allowed to analyze the previous days (Fig. 4a) and the date of the first bloom detection in August 28 (Fig. 4b), which indicated a high concentration in that area with an estimate for the nearest pixel of $11.76 \mathrm{mg} \mathrm{Chlo-a} \mathrm{m}^{-3}$ (average of 9 nearest pixels $=4.08 \mathrm{mg}$ Chlo-a m${ }^{-3}, \mathrm{CV}=$ 0.98). The set of images obtained between August 25-28 determined that the first bloom detection occurred within a long and broad band of high chlorophyll-a concentration with values of 10-20 mg Chlo-a $\mathrm{m}^{-3}$, which spread along the outer shelf adjacent to the shelf break between $\sim 37^{\circ}$ and $39^{\circ} 30^{\prime} \mathrm{S}$ and with two extensions towards the oceanic basin. The second detection of the A. cf. spinosum bloom was observed inside what in satellite images appears as a narrow strip continuing south from the first broad band (up to $\sim 41^{\circ} \mathrm{S}$ ), and which was also located on the outer shelf following approximately the contour of the shelf break (Fig. 4c, d). The estimated chlorophyll-a concentration
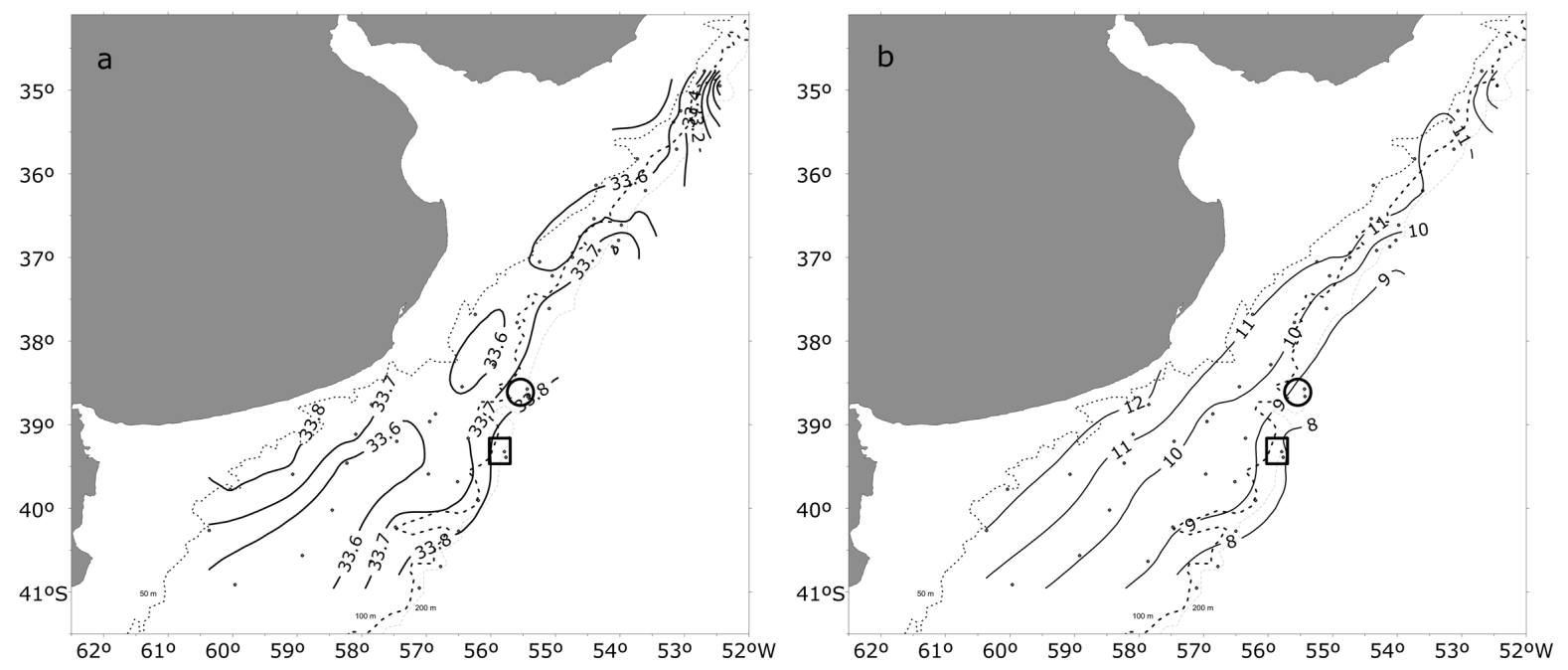

Figure 3. Areas of water discolorations caused by Azadinium cf. spinosum registered in the two parts of the CC-11/98 cruise and distribution of salinity (a) and temperature in ${ }^{\circ} \mathrm{C}(\mathrm{b})$ in the surface area covered by the EH-08/98 cruise (August 1998; dots: location of stations). CC-11/98 $1^{\text {st }}$ part: August 28, 1998 (circle); CC-11/98 2 $2^{\text {nd }}$ part: September 5, 1998 (square) / Áreas de discoloraciones causadas por Azadinium cf. spinosum registradas en las dos etapas de la campaña CC-11/98 y distribución de salinidad (a) y temperatura en ${ }^{\circ} \mathrm{C}$ (b) de superficie en el área cubierta por la campaña EH-08/98 (agosto 1998; puntos: localización de estaciones). 1a Etapa CC-11/98: 28 agosto 1998 (círculo); $2^{\text {da }}$ etapa CC-11/98: 5 septiembre 1998 (cuadrado) 

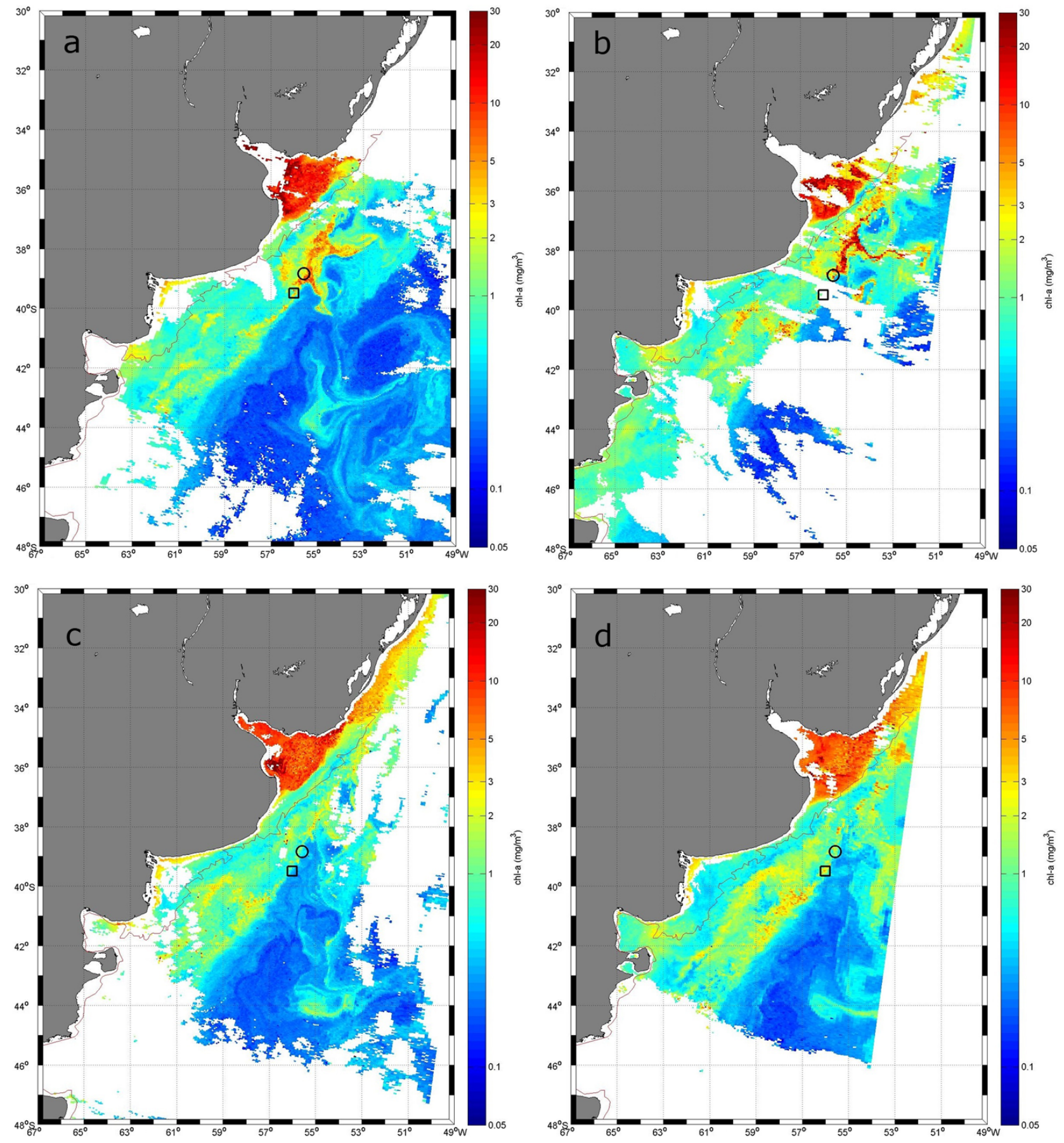

Figure 4. Satellite images of chlorophyll-a from the SeaWiFS sensor during the period of A. cf. spinosum bloom in 1998. Daily images correspond to August 25 (a), August 28 (b), August 30 (c), and September 6, 1998 (d). Circles and squares correspond to the 2 areas of water discolorations detected in August 28 and September 5, respectively / Imágenes satelitales de distribución de clorofila-a del sensor SeaWiFS durante el período de la floración de A. cf. spinosum en 1998. Imágenes diarias correspondientes al 25 de agosto (a), 28 de agosto (b), 30 de agosto (c) y 6 de septiembre de 1998 (d). Los círculos y cuadrados corresponden respectivamente a las 2 áreas de discoloraciones detectadas el 28 de agosto y 5 de septiembre 
in this second area and date of detection was significantly lower than in the first one, with a value for the nearest pixel of $2.03 \mathrm{mg}$ Chlo-a ${ }^{-3}$ (average of 9 nearest pixels= $2.47 \mathrm{mg}$ Chlo-a m${ }^{-3}, \mathrm{CV}=0.64$ ). During the period between in situ observations, satellite images showed considerable variation in color, falling steeply on August 30 in the northern area to values of $<1 \mathrm{mg}$ Chlo-a $\mathrm{m}^{-3}$, to slowly increase to $3-5 \mathrm{mg}$ Chlo-a $\mathrm{m}^{-3}$ to the date of the second detection. The analysis of wind records pointed out that between August 29 and 31 there were increases in wind velocity that reached a maximum of $46 \mathrm{~km} \mathrm{~h}^{-1}$ ( $v s$ max. of $11 \mathrm{~km} \mathrm{~h}^{-1}$ in the previous days) suggesting that this factor could have been a possible cause of the sudden decrease in satellite color signal. Increases in wind speed could have caused the mixing of the upper layers of the water column, thus decreasing the abundance of phytoplankton at the surface.

Together with the band of high chlorophyll-a values adjacent to the shelf break, satellite images showed that in a middle shelf area $\left(\sim 38^{\circ} 30^{\prime}-39^{\circ} 30^{\prime} \mathrm{S}\right.$, isobaths $50-100$ $\mathrm{m})$ there was also higher chlorophyll concentration (3-5 $\mathrm{mg}$ Chlo-a $\mathrm{m}^{-3}$ ) than in the surrounding area (Fig. 4). These high values decreased on the same date that in the slope, and they also slowly increased to the date of the second detection. For this reason, a common cause as the aforementioned increase in wind speed could explain these variations. Although there were no samples in the middle shelf during this period and information on phytoplankton composition is lacking, a high concentration of $A$. cf. spinosum was recorded two months later at the more coastal location of the EPEA station (see next paragraph).

\section{Annual CyCle}

The presence and abundance of Azadinium were studied at the time-series station EPEA located $~ 12$ nautical miles from the coast between May 1994 and November 2000 (Fig. 5). This was recorded for all years except 1999, detected in 13 of the 56 cruises, and occurred mainly during the warm period in spring (SON, 4 cruises), summer (DJF, 3 cruises) and autumn (MAM, 5 cruises), and only occasionally in winter (JJA, 1 cruise). Although visits to the EPEA were occasional, seasonality was particularly evident during years of more frequent sampling (1994-95, 1997-98), with occurrence of Azadinium from late spring (October 18, first detection) to early summer (January 5), and during most of the autumn period (March 29 to June 7).

Cells of Azadinium were recorded at every level of the water column. Abundance was low throughout the analyzed period (except spring 1998) with cell concentrations rarely exceeding 400 cells $\mathrm{L}^{-1}$ and a maximum value of 960 cells $\mathrm{L}^{-1}$. Only an episode of higher cell concentration of over two orders of magnitude occurred in November 1998, when a maximum of $28 \times 10^{3}$
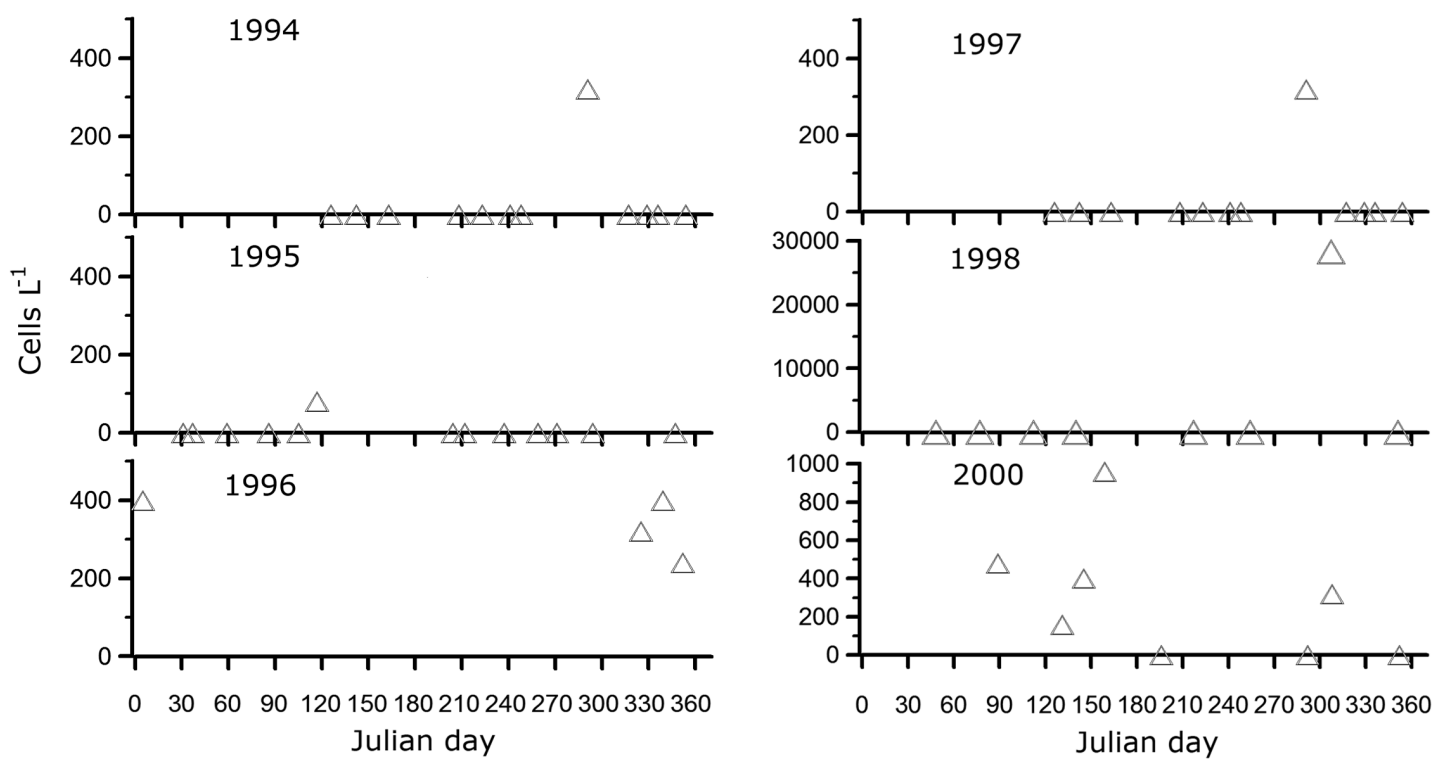

Figure 5. Presence and abundance of Azadinium at the EPEA station during the period May 1994-November 2000. Cell concentration values correspond to the maximum estimated in the water column in each cruise / Presencia y abundancia de Azadinium en la estación EPEA durante el período mayo 1994-noviembre 2000. Los valores de concentración celular corresponden a los máximos estimados en la columna de agua en cada campaña 
cells $\mathrm{L}^{-1}$ was recorded two months after the bloom at the shelf break. Azadinium was not present in this coastal station during the previous months of August and September (Fig. 5) when it was the dominant species in plankton communities at the shelf break. This population maximum at the EPEA was recorded at $24 \mathrm{~m}$ depth near the thermocline and the maximum chlorophyll fluorescence depth in the water column (see Fig. 8), where Azadinium (83\% of phytoplankton cells in the 10-200 $\mu \mathrm{m}$ size fraction) was a member of a community also composed by the diatoms Nitzschia longissima (Brébisson) Ralfs, Odontella sinensis (Greville) Grunow, Pleurosigma normanii Ralfs and Thalassiosira sp. and the photosynthetic dinoflagellates Neoceratium dens (Ostenfeld et Schmidt) F. Gomez, D. Moreira et P. LopezGarcia and Neoceratium fusus (Ehrenberg) F. Gomez, D. Moreira et P. Lopez-Garcia.

Cell proportion of Azadinium in all other periods of spring, autumn and summer was generally less than $1 \%$, in communities that were characterized by a predominance of diatoms (Ditylum brightwellii (T.West) Grunow, Ceratoneis closterium Ehrenberg, T. nitzschioides, species of Thalassiosira, Pseudo-nitzschia, Leptocylindrus, Cerataulina, Rhizosolenia, Chaetoceros, Hemiaulus and Guinardia) over dinoflagellates (Alexandrium tamarense (Lebour) Balech, Gyrodinium fusus (Meunier) Akselman, Noctiluca scintillans (Macartney) Kofoid et Swezy, species of Neoceratium, Gymnodinium, Dinophysis and Amphidinium), and also being constituted by silicoflagellates, euglenophytes and prasinophytes.

\section{ENVIRONMENTAL CONDITIONS}

The range of salinity and temperature associated with the presence of Azadinium were 33.4-33.9 and $7.3-19.3^{\circ} \mathrm{C}$, respectively (Fig. 6). These values comprise the whole data of the 1993 cruise, the 1998 bloom area and all the samplings at the EPEA station. Its amplitude represents both the different water masses of the region and seasonal variations that occur at the time-series station. In late winter and early spring of 1993, the spatial distribution of Azadinium in Argentine and Uruguayan shelves was recorded in waters of low temperature $\left(7.3-9.9^{\circ} \mathrm{C}\right)$ and salinity values of wide dispersion (33.4-33.9) (Figs. 2 and 6).

In 1998, during a cruise carried out in the period immediately before the detection of the $A$. cf. spinosum bloom, the outer shelf sector showed a thermocline at $\sim 30-50 \mathrm{~m}$ depth (gradient $\sim 2.5^{\circ} \mathrm{C}$ ), low temperature (7.7$8.9^{\circ} \mathrm{C}$ ) and high salinity (33.8-33.9) in surface waters (Figs.

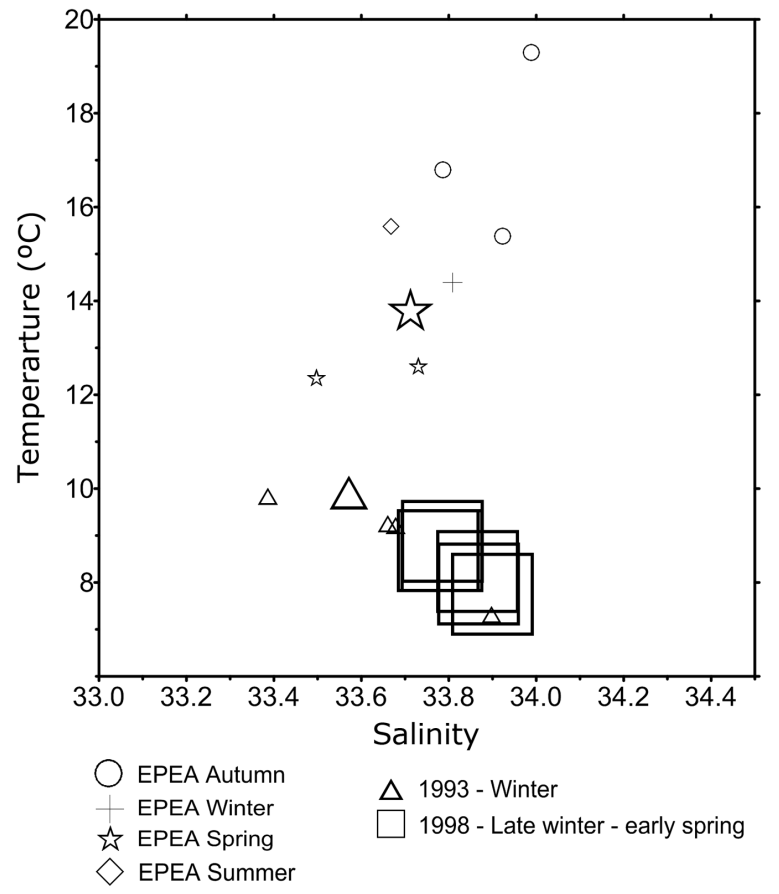

Figure 6. Temperature and salinity values of samples with presence of Azadinium at EH-10/93 and EH-08/98 cruises of 1993 and 1998 respectively, and at the EPEA station during the period May 1994November 2000 . The size of the symbols corresponds to cell concentration (circles, cross, rhombus, small stars: $\leq 960$ cells $\mathrm{L}^{-1}$; large star: $2810^{3}$ cells $\mathrm{L}^{-1}$; small triangles: $<10^{3}$ cells $\mathrm{L}^{-1}$; large triangle: $3510^{3}$ cells $\mathrm{L}^{-1}$; squares: $>10^{6}$ cells $\mathrm{L}^{-1}$ ) / Valores de temperatura y salinidad de muestras con presencia de Azadinium procedentes de las campañas EH-10/93 y EH-08/98 de 1993 y 1998 respectivamente, y de la estación EPEA durante el período mayo 1994-noviembre 2000. El tamaño de los símbolos corresponde a la concentración de células

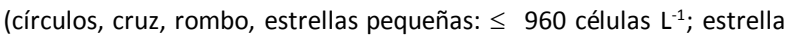
grande: $2810^{3}$ células $\mathrm{L}^{-1}$; triángulos pequeños: $<10^{3}$ células $\mathrm{L}^{-1}$; triángulo grande: $3510^{3}$ células $\mathrm{L}^{-1}$; cuadrados: $>10^{6}$ células $\mathrm{L}^{-1}$ )

3 and 6), indicating the influence of the neighboring cold and saline waters of the Malvinas Current. Of particular interest was the hydrographic structure of the water column in a station close in time and position to the date of the first bloom detection (St 674, August 23, 38³4'S, $\left.55^{\circ} 26^{\prime} \mathrm{W}\right)$. In addition to the thermocline in depth, a layer of higher temperature and lower salinity was observed developing between the surface and $\sim 10 \mathrm{~m}$ depth and differentiated by a thermohaline gradient evolved between 10 and $15 \mathrm{~m}$ (Fig. 7).

Temperature values associated with the presence of Azadinium at the EPEA station $\left(12.3-19.3^{\circ} \mathrm{C}\right)$ were greater than those recorded in the middle and outer shelf (Fig. 6), particularly those related not only with the coastal-oceanic 


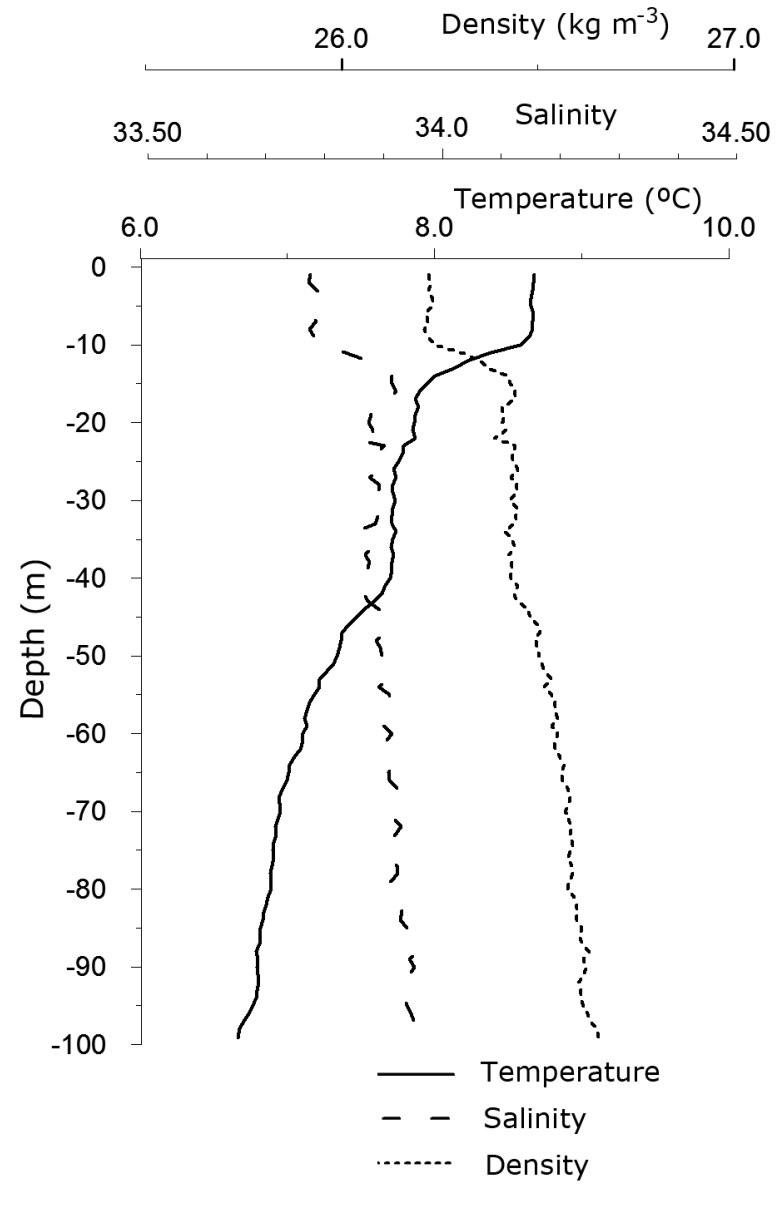

Figure 7. Vertical distribution of temperature, salinity and density at station 674 of the EH-08/98 cruise, located in the area of the A. cf. spinosum bloom of 1998 / Distribución vertical de temperatura, salinidad y densidad en la estación 674 de la campaña EH-08/98, situada en el área de la floración de A. cf. spinosum del año 1998

gradient but also with the seasonal period. Indeed, while the 1998 bloom in the outer shelf occurred during late winter, the presence of Azadinium at the EPEA was recorded mainly in spring and autumn, periods when the water column showed higher temperature.

The highest record of Azadinium concentration at the EPEA, which occurred in 1998 two months after the bloom of $A$. cf. spinosum in the outer shelf, was associated with the location of the thermocline (Fig. 8). Its vertical distribution of abundance indicated low values in the upper levels of the water column $\left(<10^{3}\right.$ cells $\left.\mathrm{L}^{-1}\right)$ and a significant increase above the thermocline $\left(28 \times 10^{3}\right.$ cells $\mathrm{L}^{-1}, 24 \mathrm{~m}$ depth). The vertical profile of phytoplankton,

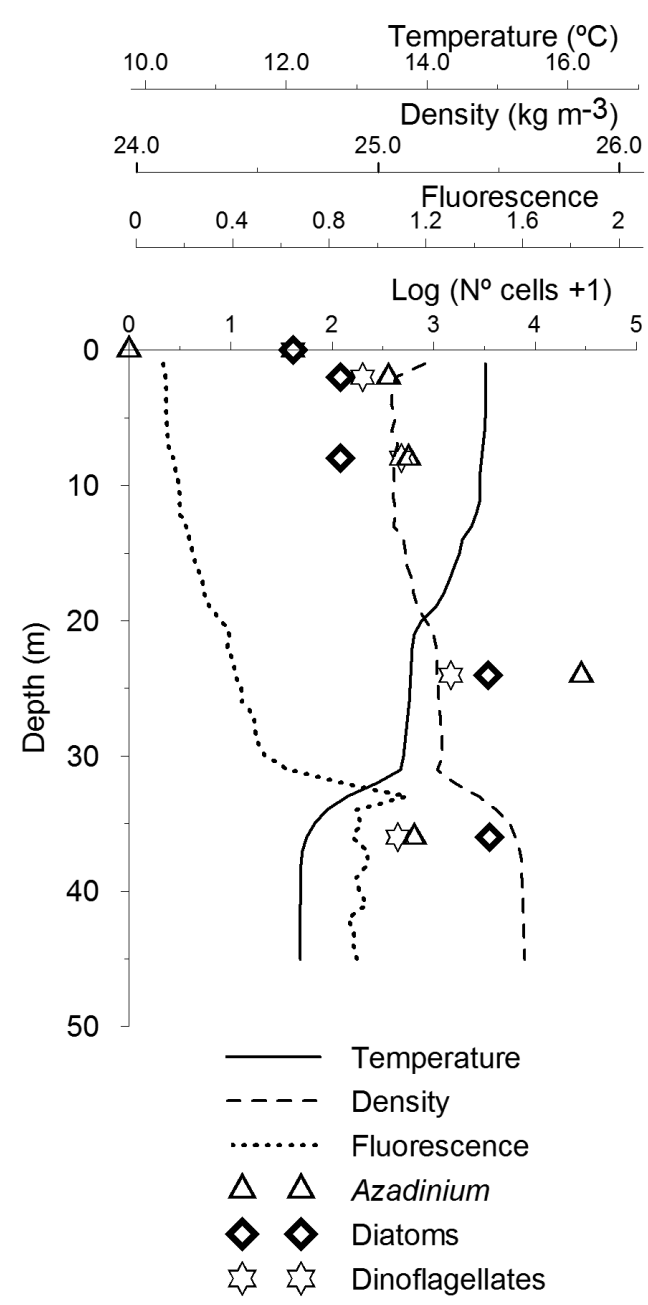

Figure 8. Vertical distribution of temperature, density and chlorophyll fluorescence and abundance of Azadinium and other phytoplankton groups at the EPEA station on November 3, 1998 (CC-15/98 cruise) / Distribución vertical de temperatura, densidad y fluorescencia de clorofila y abundancia de Azadinium y de otros grupos de fitoplancton en la estación EPEA de fecha 3 de noviembre de 1998 (campaña CC-15/98)

mainly composed of diatoms and photosynthetic dinoflagellates, had a similar abundance distribution, with a fluorescence maximum also present at the same depth of the thermocline (Fig. 8). Thus, the highest concentration of Azadinium in the EPEA was recorded at a depth level immediately above the fluorescence maximum and the location of the pycnocline, which in this case of low salinity variation corresponded with the thermocline. 


\section{Discussion}

The spatial distribution of Azadinium recorded in this study was extensive, spanning approximately 2.5 degrees of latitude. The area included part of that covered by the blooms of 1990 and 1991 in the northern Argentine shelf (Akselman \& Negri 2012), and extended to the mouth of the Río de la Plata and southern shelf waters of Uruguay. Thereby, the overall geographic distribution of Azadinium in the SWA ranges from $34^{\circ} 30^{\prime}$ to $40^{\circ} 20^{\prime} \mathrm{S}$. A quantitative analysis that was carried out for more than six years at the EPEA time-series station and during a regional cruise, showed generally low cell abundances, with only two higher values recorded at the EPEA and off the mouth of the Río de la Plata. However, in late winter 1998, an intense bloom with densities $>1 \times 10^{6}$ cells $\mathrm{L}^{-1}$ causing water discolorations was detected in outer shelf waters adjacent to the shelf break. This was the third record of a bloom caused by A. cf. spinosum occurring in the same area of those previously documented at the beginning of the 1990s (Akselman \& Negri 2012). As suggested in the latter study and although its life cycle is not known, it is possible that like other dinoflagellates (Dale 1983), A. cf. spinosum could produce resting cysts which after germination develop into the flagellate vegetative stage able to grow and to increase population levels. The process is possible in this shelf area subject to an annual regime of mixing and stratification (Guerrero \& Piola 1997). The capacity of hypnocyst formation has not been fully documented in the genus Azadinium, but it should be mentioned that $A$. polongum in culture could produce cysts of long persistence whose vegetative or sexual origin as part of its life cycle is unknown (Tillmann et al. 2012a), and also, that different strains of A. poporum have been isolated in culture from samples of sediment (Potvin et al. 2012, Gu et al. 2013).

This third bloom of $A$. cf. spinosum occupied an extensive area and lasted for a prolonged period, spanning 40' in latitude and 25' in longitude and elapsing 9 days between each of the reports and samplings. This in situ bloom was detected by SeaWiFS color images corresponding to the days when discolorations were reported (August 28 and September 5, 1998), as well as those from the previous period and in between samplings. These images showed high surface concentrations of chlorophyll-a in positions at which $A$. cf. spinosum attained high cell abundances. Thus, satellite images allowed following the extension of this bloom in time and space. These SeaWiFS images showed that the first detection of the $A$. cf. spinosum bloom was within a wide and long strip of high chlorophyll-a concentration that extended over $\sim 2.5$ latitudinal degrees in the outer shelf adjacent to the slope and extending to the oceanic basin, while the second detection was localized within a narrow strip continuing to the south and also contouring the shelf break. Although the possibility that the development of the A. cf. spinosum bloom was of large spatial extent is still speculative since sampling was limited, there are several reports of blooms encompassing big areas in the Argentine Sea. As regards latitude, extensive phytoplankton developments are possible in this region in which blooms of Gyrodinium cf. aureolum (=Karenia mikimotoi) and other dinoflagellates have been documented (Negri et al. 1992a, b). Blooms of diatoms as Thalassiosira have also been registered with evolvements along $~ 8$ degrees along the shelf break front and the Malvinas Current (R. Akselman, unpublished results). Integrated monthly satellite images for 1998 pointed out that the spring phytoplankton bloom in the outer shelf near the shelf break began in August and remained with variations in intensity until November (see Appendix 1). A. cf. spinosum was undoubtedly an important component of the spring bloom of that year. Its high population levels and the fact that it accounted for $>95 \%$ of the photosynthetic cells in the $10-200 \mu \mathrm{m}$ size range indicates that it could have been implicated in a substantial part of the high chlorophyll-a satellite signal at the beginning of the spring productive season in the frontal area of the shelf break. High chlorophyll-a concentrations and primary production values are found in the frontal area at the shelf-break, where satellite images show a band of maximum chlorophyll-a concentration, which in some years could extend up to $\sim 1500 \mathrm{~km}$ between 37 and $51^{\circ} \mathrm{S}$ (Carreto et al. 1995, Rivas et al. 2006, Romero et al. 2006, Lutz et al. 2010).

The temporal analysis of the distribution of Azadinium at the EPEA indicated a marked seasonality with most of the records during spring and autumn. Previous blooms of A. cf. spinosum occurred in late spring (November 1990) and early spring (September 1991) (Akselman \& Negri 2012), but the 1998 bloom on late winter-early spring (August-September) is the earliest occurrence observed during the annual period. This early annual growth of $A$. cf. spinosum leads us to consider it as a species that seems to be successful in the first stage of the spring phytoplankton development, as suggested by Akselman $\&$ Negri (2012), who observed it as a good competitor of chained species of Thalassiosira. 
During the six years of study at the EPEA, Azadinium showed low densities except for a single episode of higher concentration in November 1998, two months after the detection of its bloom in the outer shelf. These two events may very well have been related but we lack any data showing such a link. The simultaneous observation in satellite images of higher chlorophyll-a values in the middle shelf during the occurrence of the $A$. cf. spinosum bloom in the outer shelf raises the question of a possible development of the species on the middle shelf which, by advection, could have arrived to more coastal waters. This scenario is probable, since $A$. cf. spinosum was the dominant species in a phytoplankton biomass maximum developed in 1991 along a section of $\sim 40 \mathrm{~km}$ in the middle shelf (Akselman \& Negri 2012). Additionally, it should not be ruled out that part of the population growth could have occurred at the EPEA, where the formation of a seasonal coastal front, linked to increase in phytoplankton, has been reported (e.g., Carreto et al. 1995, Lucas et al. 2005).

Environmental conditions for the development of Azadinium have been linked both to the hydrographic features of regional water masses and to variations in the water column produced during the annual cycle, which showed a wide range of temperature and salinity values. This genus has been present in middle and outer shelf waters in Argentina and in lower salinity waters in Uruguay, due possibly to an overturning of the Río de la Plata plume (Campos et al. 2008). At the EPEA its presence has been linked to the annual period of increased temperature of the water column. The 1998 bloom of $A$. cf. spinosum occurred in the outer shelf adjacent to the shelf break, an area under the influence of the Malvinas Current. Here, hydrographic conditions at the beginning of the development of the annual thermocline showed a low density and high temperature layer occurring between the surface and $\sim 10 \mathrm{~m}$ depth, separated by a weak gradient from deeper waters. As nutrient availability during late winter is high (Carreto et al. 1995), this type of hydrographic structure with a not too thick upper layer of low density, where light was not limited, may have represented an important factor allowing the growth of $A$. cf. spinosum. Similar environmental conditions associated with population growth in surface and subsurface layers have been reported for other dinoflagellates in this area (Negri et al. 1992a, b), and are also known in other regions (e.g., Zingone \& Wyatt 2004).

Although Jauffrais et al. (2013) reported that $A$. spinosum in culture grows in a wide range of temperature and salinity values, which partly includes those observed for Azadinium in the SWA, A. spinosum achieves higher growth rates and/or production at temperatures of 18 $22^{\circ} \mathrm{C}$. However, in correspondence with North Atlantic records for other species of this genus, the high population densities of $A$. cf. spinosum in 1991 (Akselman $\&$ Negri 2012) and 1998 occurred at markedly lower temperature values which ranged from $\sim 8-10^{\circ} \mathrm{C}$. Indeed, A. spinosum and $A$. polongum have been observed in the Shetland Is. at $10^{\circ} \mathrm{C}$ (Tillmann et al. 2012a), a temperature at which cultures of $A$. spinosum can reach, with low growth rates, concentrations of $>10^{6}$ cells $\mathrm{L}^{-1}$ (Jauffrais et al. 2013). Therefore, Azadinium appears to be an example of dinoflagellate able to grow along a gradient of environmental conditions. Thus, in areas where the supply of nutrients is coupled to the mixing and turbulence, this genus seems to have different ecological requirements in the sequence of main events postulated by the classic Margalef's mandala (see Zingone \& Wyatt 2004).

During periods in which $A$. cf. spinosum has been an important component of the spring increase in phytoplankton, its biomass may not only have been incorporated to the pelagic ecosystem but also to the benthos. After the spring bloom, when oceanographic conditions allow sedimentation of food particles to the ocean floor, it could have contributed to the growth of bivalves. This mechanism has been proposed for the scallop Zygochlamys patagonica (Schejter et al. 2002, Bogazzi et al. 2005) and could also be applied for Mytilus edulis, whose benthic beds are commercially exploited (Lasta et al. 1998, Ciocco et al. 2006).

The taxonomic study of $A$. cf. spinosum is currently ongoing. Morphologically, the existence and position of a ventral pore at the epitheca are under analysis. This character has proven to be important to discriminate species belonging to the genus and is correlated with results of molecular phylogeny based mainly on the phylogenetic analysis of nuclear-encoded ribosomal genes based on the large and small ribosomal subunits (Tillmann et al. 2009, 2010, 2011, 2012a, b, Percopo et al. 2013, Tillmann et al. 2014). A. cf. spinosum has an antapical spine, a trait which shares in common with A. spinosum (Tillmann et al. 2009), A. dexteroporum (Percopo et al. 2013), A. dalianense (Luo et al. 2013), A. trinitatum and A. concinnum (Tillmann et al. 2014), but differences in cell dimensions and in the shape of some plates in addition to the unknown position of the ventral pore prevents its identification. 
Although we still do not know if $A$. cf. spinosum produces azaspiracids, the high cell densities of its blooms are within the range of $A$. spinosum concentrations used in feeding experiments that caused a rapid accumulation of AZA toxins in M. edulis (Salas et al. 2011). Recent evidences of AZAs production in the SWA with the detection of AZA-1 and AZA-2 in mussels from coastal hatcheries in Brazil (Schramm et al. ${ }^{1}$ ) and of AZA2 produced in culture by an Azadinium species isolated from the northern Argentine shelf (B. Krock \& U. Tillmann, pers. comm. ${ }^{4}$ ), point out the need to continue with studies of $A$. cf. spinosum taking into account the ecological importance that it has shown in this region.

\section{ACKNOWLEDGMENTS}

To F. Lopez for his cooperation with satellite images in an early step of this work. To the INIDEP colleagues M. Lasta for samples from the bloom areas, G. Cañete for samples from the EH-10/93 cruise, A. Baldoni for providing access to oceanographic data, and specially to G.N. Molinari for meteorological information. To the crews of the R/Vs Cap. Cánepa, E.L. Holmberg and Cap. Oca Balda from INIDEP. We are greatly indebted to two anonymous reviewers for constructive suggestions. This is Contribution $\mathrm{N}^{\circ} 1884$ of the Instituto Nacional de Investigación y Desarrollo Pesquero (INIDEP), Mar del Plata, Argentina.

\section{LITERATURE CITED}

Akselman R \& RM Negri. 2012. Blooms of Azadinium $c f$. spinosum Elbrächter $e t$ Tillmann (Dinophyceae) in northern shelf waters of Argentina, Southwestern Atlantic. Harmful Algae 19: 30-38.

Bogazzi E, AG Baldoni, A Rivas, P Martos, R Reta, JM Orensanz, ML Lasta, OP Dell'Arciprete \& AF Werner. 2005. Spatial correspondence between areas of concentration of Patagonian scallop (Zygochlamys patagonica) and frontal systems in the southwestern Atlantic. Fisheries Oceanography 14(5): 359-376.

Campos EJD, AR Piola, RP Matano \& JL Miller. 2008. PLATA: A synoptic characterization of the southwest Atlantic shelf under influence of the Plata River and Patos Lagoon outflows. Continental Shelf Research 28(13): 15511555.

Carreto JI, VA Lutz, MO Carignan, AD Cucchi-Colleoni \& SG De Marco. 1995. Hydrography and chlorophyll-a in a transect from the coast to the shelf-break in the Argentinean Sea. Continental Shelf Research 15: 315-336.
Ciocco NF, ML Lasta, M Narvarte, C Bremec, E Bogazzi, J Valero \& JM Orensanz. 2006. Scallops fisheries in Argentina. In: Shumway S \& GJ Parson (eds). Developments in aquaculture and fisheries sciences. Scallops: biology, ecology and aquaculture, pp. 1251-1292. Elsevier, Amsterdam.

Colman JR, MJ Twiner, P Hess, T McMahon, M Satake, T Yasumoto, GJ Doucette \& JS Ramsdell. 2005. Teratogenic effects of azaspiracid-1 identified by microinjection of Japanese medaka (Oryzias latipes) embryos. Toxicon 45: 881-890.

Dale B. 1983. Dinoflagellate resting cysts: 'benthic plankton'. In: Fryxell GA (ed). Survival strategies of the algae, pp. 69136. Cambridge University Press, Cambridge.

Furey A, S O'Doherty, K O'Callaghan, M Lehane \& KJ James. 2010. Azaspiracid poisoning (AZP) toxins in shellfish: Toxicological and health considerations. Toxicon 56: 173-190.

Gu H, Z Luo, B Krock, M Witt \& U Tillmann. 2013. Morphology, phylogeny and azaspiracid profile of Azadinium poporum (Dinophyceae) from the China Sea. Harmful Algae 21-22: 64-75.

Guerrero RA \& AR Piola. 1997. Masas de agua en la plataforma continental. En: Boschi EE (ed). El Mar Argentino y sus recursos pesqueros. 1. Antecedentes históricos de las exploraciones en el mar y las características ambientales, pp. 107-118. Publicaciones Especiales INIDEP, Mar del Plata.

Guiry MD \& GM Guiry. 2014. AlgaeBase. World-wide electronic publication, National University of Ireland, Galway. 〈http://www.algaebase.org>

Hasle GR. 1978. The inverted-microscope method. In: Sournia A (ed). Phytoplankton manual 6: 88-96. UNESCO Monographs on Oceanographic Methodology, Paris.

Hernández-Becerril DU, SA Barón-Campis \& S EscobarMorales. 2012. A new record of Azadinium spinosum (Dinoflagellata) from the tropical Mexican Pacific. Revista de Biología Marina y Oceanografía 47(3): 553-557.

Ito E, M Satake, K Ofuji, M Higashi, K Harigaya, T McMahon \& T Yasumoto. 2002. Chronic effects in mice caused by oral administration of sublethal doses of azaspiracid, a new marine toxin isolated from mussels. Toxicon 40: 193-203.

James KJ, A Furey, M Lehane, H Ramstad, T Aune, P Hovgaard, S Morris, W Higman, M Satake \& T Yasumoto. 2002. First evidence of an extensive Northern European distribution of Azaspiracid Poisoning (AZP) toxins in shellfish. Toxicon 40: 909-915.

Jauffrais T, V Séchet, C Herrenknecht, P Truquet, V Savar, U Tillmann \& P Hess. 2013. Effect of environmental and nutritional factors on growth and azaspiracid production of the dinoflagellate Azadinium spinosum. Harmful Algae 27: 138-148. 
Krock B, U Tillmann, U John \& A Cembella. 2009. Characterization of azaspiracids in plankton size-fractions and isolation of an azaspiracid-producing dinoflagellate from the North Sea. Harmful Algae 8: 254-263.

Krock B, U Tillmann, D Voß, BP Koch, R Salas, M Witt, É Potvin \& HJ Jeong. 2012. New azaspiracids in Amphidomataceae (Dinophyceae). Toxicon 60(5): 830-839.

Lasta ML, NF Ciocco, CS Bremec \& A Roux. 1998. Moluscos bivalvos y gasterópodos. En: Boschi EE (ed). El Mar Argentino y sus recursos pesqueros. 2. Los moluscos de interés pesquero. Cultivos y estrategias reproductivas de bivalvos y equinoideos, pp. 115-142. Publicaciones Especiales INIDEP, Mar del Plata.

Lucas AJ, RA Guerrero, HW Mianzan, EM Acha \& CA Lasta. 2005. Coastal oceanographic regimes of the Northern Argentine Continental Shelf (34-43S). Estuarine Coastal and Shelf Science 65: 405-420.

Luo Z, H Gu, B Krock \& U Tillmann. 2013. Azadinium dalianense, a new dinoflagellate species from the Yellow Sea, China. Phycologia 52: 625-636.

Lutz VA, V Segura, AI Dogliotti, DA Gagliardini, AA Bianchi \& CF Balestrini. 2010. Primary production in the Argentine Sea during spring estimated by field and satellite models. Journal of Plankton Research 32(2): 181-195.

Magdalena AB, M Lehane, S Krys, ML Fernández, A Furey \& KJ James. 2003. The first identification of azaspiracids in shellfish from France and Spain. Toxicon 42: 105-108.

Margalef R. 1978. Life-forms of phytoplankton as survival alternatives in an unstable environment. Oceanologica Acta 1: 439-509.

McMahon T \& J Silke. 1996. West coast of Ireland; winter toxicity of unknown aetiology in mussels. Harmful Algae News 14: 2 .

Negri RM, R Akselman \& HR Benavides. 1992a. Floración excepcional de un dinoflagelado en aguas de las plataformas argentina y uruguaya. Frente Marítimo 11: 115-122.

Negri RM, JI Carreto, HR Benavides, R Akselman \& VA Lutz. 1992b. An unusual bloom of Gyrodinium cf. aureolum in the Argentine Sea. Community structure and conditioning factors. Journal of Plankton Research 14(2): 261-269.

Nézan E, U Tillmann, G Bilien, S Boulben, $K$ Chèze, F Zentz, R Salas \& N Chomérat. 2012. Taxonomic revision of the dinoflagellate Amphidoma caudata: transfer to the genus Azadinium (Dinophyceae) and proposal of two varieties, based on morphological and molecular phylogenetic analyses. Journal of Phycology 48: 925-939.

Odebrecht C. 2010. Dinophyceae. Em: Forzza RC (ed). Catálogo de plantas e fungos do Brasil 1, pp. 366-383. Instituto de Pesquisas, Jardim Botânico do Rio de Janeiro, Rio de Janeiro.
O'Reilly JE, S Maritorena, BG Mitchell, DA Siegel, KL Cardel, SA Garver, M Kahru \& C McClain. 1998. Ocean color chlorophyll algorithms for SeaWiFS. Journal of Geophysical Research-Oceans 103(C11): 24937-24953.

O'Reilly JE, S Maritorena, D Siegel, MC O'Brien, D Toole, BG Mitchell, M Kahru, FP Chavez, P Strutton, G Cota, SB Hooker, CR McClain, KL Carder, F MullerKarger, L Harding, A Magnuson, D Phinney, GF Moore, J Aiken, KR Arrigo, R Letelier \& M Culver. 2000. Ocean color chlorophyll-a algorithms for SeaWiFS, OC2 and OC4: Version 4. In: Hooker SB \& ER Firestone (eds). SeaWiFS post-launch technical report series. SeaWiFS post-launch calibration and validation analyses 11(Part 3): 9-23. NASA/ GSFC, Maryland.

Percopo I, R Siano, R Rossi, V Soprano, D Sarno \& A Zingone. 2013. A new potentially toxic Azadinium species (Dinophyceae) from the Mediterranean Sea, $A$. dexteroporum sp. nov. Journal of Phycology 49(5): 950966.

Postek MT, KS Howard, AH Johnson \& KL McMichael. 1980. Scanning Electron Microscopy: A student's Handbook, 305 pp. Ladd Research Industries, Williston.

Potvin E, HJ Jeong, NS Kang, U Tillmann \& B Krock. 2012. First report of the photosynthetic dinoflagellate genus Azadinium in the Pacific Ocean: morphology and molecular characterization of Azadinium cf. poporum. Journal of Eukaryotic Microbiology 59(2): 145-156.

Rehmann N, P Hess \& MA Quilliam. 2008. Discovery of new analogs of the marine biotoxin azaspiracid in blue mussels Mytilus edulis by ultra-performance liquid chromatography/tandem mass spectrometry. Rapid Communications in Mass Spectrometry 22: 549-558.

Rivas AL, AI Dogliotti \& DA Gagliardini. 2006. Seasonal variability in satellite-measured surface chlorophyll in the Patagonian Shelf. Continental Shelf Research 26: 703-720.

Romero SI, AR Piola, M Charo \& CAE García. 2006. Chlorophyll-a variability off Patagonia based on SeaWiFS data. Journal of Geophysical Research: Oceans 111(C5): 1978-2012.

Salas R, U Tillmann, U John, J Kilcoyne, A Burson, C Cantwell, P Hess, $\mathbf{T}$ Jauffrais \& J Silke. 2011. The role of Azadinium spinosum (Dinophyceae) in the production of azaspiracid shellfish poisoning in mussels. Harmful Algae 10: 774-783.

Satake M, K Ofuji, H Naoki, KJ James, A Furey, T McMahon, J Silke \& T Yasumoto. 1998. Azaspiracid, a new marine toxin having unique spiro ring assemblies, isolated from Irish mussels, Mytilus edulis. Journal of the American Chemical Society 120: 9967-9968. 
Schejter L, CS Bremec, R Akselman, D Hernández \& ED Spivak. 2002. Annual feeding cycle of the Patagonian scallop Zygochlamys patagonica (King and Broderip, 1832) in Reclutas Bed $\left(39^{\circ} \mathrm{S}-55^{\circ} \mathrm{W}\right)$, Argentine Sea. Journal of Shellfish Research 21(2): 553-559.

Tillmann U, M Elbrächter, B Krock, U John \& A Cembella. 2009. Azadinium spinosum gen. et $\mathrm{sp}$. nov. (Dinophyceae) identified as a primary producer of azaspiracid toxins. European Journal of Phycology 44(1): 63-79.

Tillmann U, M Elbrächter, U John, B Krock \& A Cembella. 2010. Azadinium obesum (Dinophyceae), a new nontoxic species in the genus that can produce azaspiracid toxins. Phycologia 49(2): 169-182.

Tillmann U, M Elbrächter, U John \& B Krock. 2011. A new non-toxic species in the dinoflagellate genus Azadinium: A. poporum sp. nov. European Journal of Phycology 46(1): 74-87.

Tillmann U, S Soehner, E Nézan \& B Krock. 2012a. First record of the genus Azadinium (Dinophyceae) from the Shetland Islands, including the description of Azadinium polongum sp. nov. Harmful Algae 20: 142-155.

Tillmann U, R Salas, M Gottschling, B Krock, D O’Driscoll \& M Elbrächter. 2012b. Amphidoma languida sp. nov (Dinophyceae) reveals a close relationship between Amphidoma and Azadinium. Protist 163(5): 701-719.
Tillmann U, M Gottschling, E Nézan, B Krock \& G Bilien. 2014. Morphological and molecular characterization of three new Azadinium species (Amphidomataceae, Dinophyceae) from the Irminger Sea. Protist 165(4): 417-444.

Twiner MJ, P Hess, MY Bottein-Dechraoui, T McMahon, MS Samons, M Satake, T Yasumoto, JS Ramsdell \& GJ Doucette. 2005. Cytotoxic and cytoskeletal effects of azaspiracid-1 on mammalian cell lines. Toxicon 45: 891 900.

Twiner MJ, N Rehmann, P Hess \& GJ Doucette. 2008. Azaspiracid shellfish poisoning: a review on the chemistry, ecology, and toxicology with emphasis on human health impacts. Marine Drugs 6: 39-72.

Twiner MJ, R El-Ladki, J Kilcoyne \& GJ Doucette. 2012. Comparative effects of the marine algal toxins azaspiracid$1,-2$, and -3 on Jurkat $\mathrm{T}$ lymphocyte cells. Chemical Research in Toxicology 25: 747-754.

Zingone A \& T Wyatt. 2004. Harmful algal blooms: keys to the understanding of phytoplankton ecology. In: Robinson AR \& KH Brink (eds). The sea, pp. 867-926. Harvard University Press, Cambridge. 

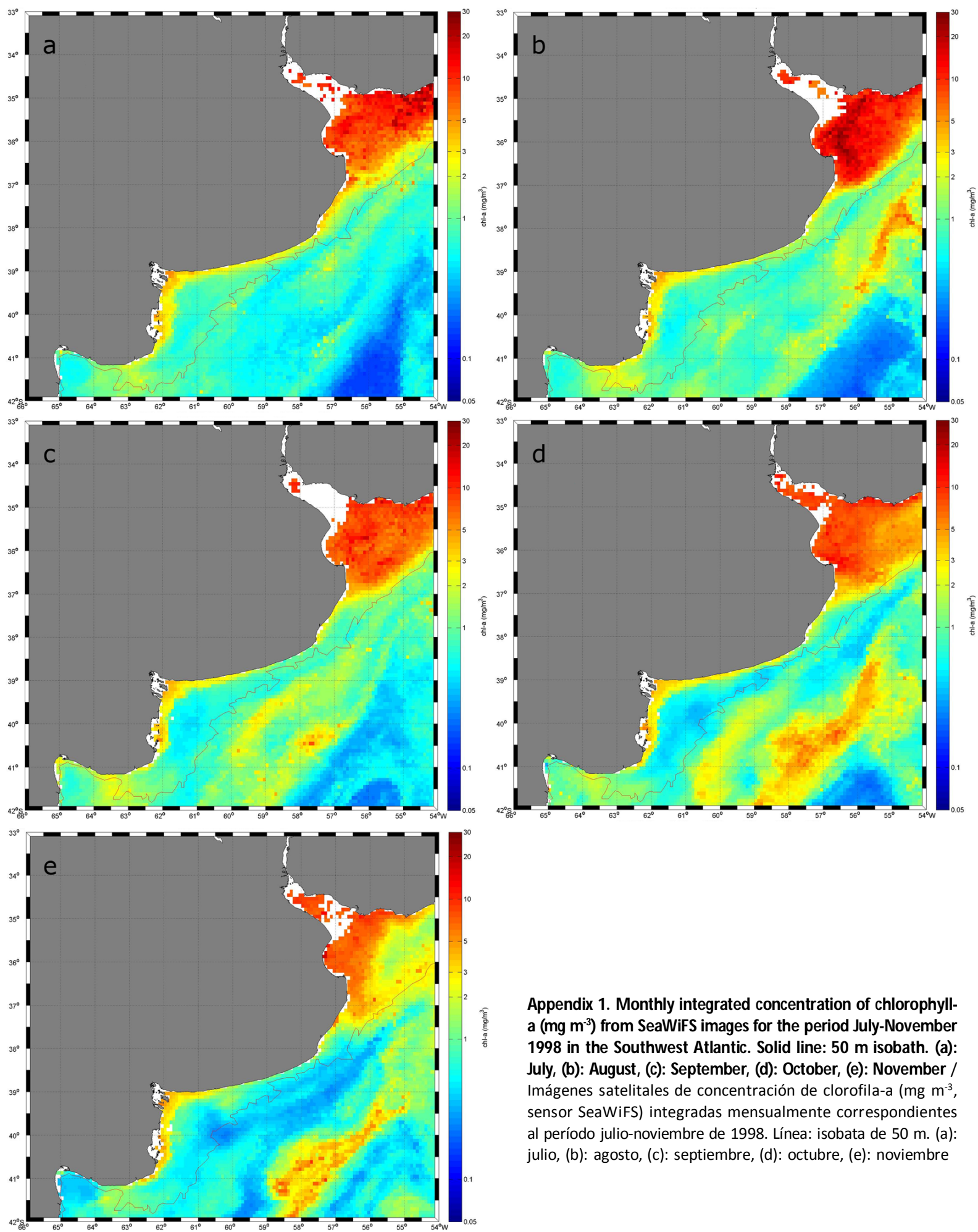

Appendix 1. Monthly integrated concentration of chlorophylla $\left(\mathrm{mg} \mathrm{m}^{-3}\right)$ from SeaWiFS images for the period July-November 1998 in the Southwest Atlantic. Solid line: $50 \mathrm{~m}$ isobath. (a): July, (b): August, (c): September, (d): October, (e): November / Imágenes satelitales de concentración de clorofila-a ( $\mathrm{mg} \mathrm{m}^{-3}$, sensor SeaWiFS) integradas mensualmente correspondientes al período julio-noviembre de 1998. Línea: isobata de $50 \mathrm{~m}$. (a): julio, (b): agosto, (c): septiembre, (d): octubre, (e): noviembre 